\title{
Global Response
}

National Cancer Institute

\section{Source}

National Cancer Institute. Global Response. NCI Thesaurus. Code C159945.

An indication of response to disease treatment that takes into account multiple body systems. 